\title{
Salt and crop production in the precolonial central sudan - or lovejoy's poorly-developed-technology thesis
}

Jouke S. Wigboldus

\section{(2) OpenEdition Journals}

Electronic version

URL: https://journals.openedition.org/tc/713

DOI: $10.4000 /$ tc. 713

ISSN: 1952-420X

\section{Publisher}

Éditions de l'EHESS

\section{Printed version}

Date of publication: 1 November 1992

ISSN: 0248-6016

\section{Electronic reference}

Jouke S. Wigboldus, "Salt and crop production in the precolonial central sudan - or lovejoy's poorlydeveloped-technology thesis", Techniques \& Culture [Online], 17-18| 1992, Online since 10 January 2006, connection on 29 September 2022. URL: http://journals.openedition.org/tc/713 ; DOl: https:// doi.org/10.4000/tc.713

This text was automatically generated on 29 September 2022.

All rights reserved 
Salt and crop production in the precolonial central sudan - or lovejoy's poorly-developedtechnology thesis

Jouke S. Wigboldus 